\title{
Tinjauan Ekonomi Islam Terhadap Usaha Bisnis Busana Muslim
}

\author{
Nur Afni ${ }^{1 *}$ Abdul Jalil ${ }^{2}$ \\ ${ }^{1}$ Jurusan Akuntansi, Pasca Sarjana Universitas Tadulako, UNTAD Palu, nur.afni \\ tadjuddin87@gmail.com \\ 1Jurusan Perbankan, Fakultas Ekonomi dan Bisnis Islam, IAIN Palu, abdul_jaliil@iainpalu.ac.id
}

ABSTRAK

Nilai-nilai dasar ekonomi Islam adalah seperangkat nilai yang telah diyakini dengan segenap keimanan, dimana ia akan menjadi landasan paradigma ekonomi Islam. Nilai-nilai dasar ini baik nilai filosofis, instrumental maupun institusional didasarkan atas Al-Qur'an dan Hadist yang merupakan dua sumber normativ tertinggi dalam agama Islam. Inilah hal utama yang membedakan ekonomi Islam dengan ekonomi konvensional, yaitu ditempatkannya sumber ajaran agama sebagai sumber utama ilmu ekonomi. Bisnis menurut Islam dapat diartikan serangkaian aktivitas bisnis dalam berbagai bentuknya yang tidak dibatasi jumlah (kuantitas) kepemilikan hartanya (barang/jasa) termasuk profitnya, namun dibatasi dalam cara dan perolehan dan pendayagunaan hartanya (aturan halal dan haram). Dengan kendali syari'at, bisnis bertujuan untuk mencapai empat hal yakni target hasil (profit materi dan benerfit non materi), pertumbuhan artinya terus meningkat, keberlangsungan dalam kurun waktu selama mungkin dan keberkahan keridhaan Allah Swt.
INFORMASI

ARTIKEL

Katakunci:

Ekonomi Islam, Usaha

Bisnis 


\section{PENDAHULUAN}

Agama Islam merupakan agama yang diturunkan oleh Allah SWT dimuka bumi untuk menjadi rahmatan lil alamin (rahmat bagi seluruh alam), Islam tidak hanya mengatur masalah ibadah seorang hamba kepada TuhanNya, tetapi juga mampu menjawab berbagai bentuk tantangan pada setiap zaman, termasuk dalam persoalan ekonomi, yang saat ini disebut sebagai ekonomi Islam. (Muhammad, 2007: 1)

Kemunculan ekonomi Islam dipandang sebagai suatu gerakan baru yang disertai dengan misi dekonstrutif atas kegagalan sistem ekonomi dunia dominan selama ini. Ekonomi Islam diikat oleh seperangkat nilai iman, akhlak dan moral etik bagi setiap aktivitas ekonominya baik dalam posisinya sebagai konsumen, produsen, distributor dan lain-lain dalam melakukan usahanya serta menciptakan hartanya. ${ }^{1}$ Aktivitas perdangan merupakan salah satu aspek kehidupan yang bersifat horizontal (hablum minannas), yang juga mendapatkan penekanan khusus dalam ekonomi Islam, karena keterkaitannya langsung dengan sektor rill, sistem ekonomi Islam memang lebih mengutamakan sektor rill, dibanding dengan sektor moneter, dan transaksi jual beli memastikan keterkaitan kedua sektor tersebut. (Jusmalinani, 2008: 8)

Dalam sistem ekonomi Islam yang menekankan pada sektor riil seperti ini, pertumbuhan bukanlah merupakan ukuran utama dalam melihat

${ }^{1}$ Nurdin, N., Novia, N., Rahman, A., \& Suhada, R. (2019). Potensi Industri Produk Makanan Halal Di Kota Palu. Jurnal Ilmu Ekonomi dan Bisnis Islam, 1(1), 1-12. perkembangan ekonomi yang terjadi, tetapi lebih pada aspek pemerataan dan pengurangan jumlah kemiskinan, kondisi seperti ini lebih memungkinkan dengan pengembangan sektor riil yang dapat menyerap tenaga kerja. Kemudian melalui pemerataan, kekayaan suatu negara tidak akan terkonsentrasi atau dikuasi oleh sekelompok orang tertentu, tetapi terdistribusikan secara merata pada anggota masyarakat yang lebih luas. (Jusmalinani, 2008: 9).

Dalam aktivitas perdagangan atau dikenal dalam istilah berbisnis pada era moderen ini, mencari keuntungan merupakan tujuan utamanya, serta praktik- praktik haram, kerap kali dilakukan untuk mendapatkan tujuan tersebut, seperti mengurangi timbangan, penjualan dua kali lipat dari harga aslinya yang jatuhnya adalah riba. Tujuan dan semua praktik-praktik tersebut dalam hukum Islam adalah suatu yang dilarang. Ekonomi Islam memandang mencari keuntungan adalah sesuatu hal yang fitrah, yang dapat menimbulkan semangat berinovasi, dan bersaing. Perhatian utama ekonomi Islam adalah upaya bagaimana manusia meningkatkan kesejahteraan materinya yang sekaligus akan meningkatkan kesejahteraan spirituanya, karena aspek spiritual harus hadir bersamaan dengan target material, maka diperlukan sarana penopang utama, yaitu moralitas pelaku ekonomi. ${ }^{2}$

${ }^{2}$ Nurdin, N., \& Mir'atun, M. a. (2018). Do Government And Private Sharia Commercial Banks Practice Similar Financial Social Responsibility Disclosure. Hunafa: Jurnal Studia Islamika, 15(2), 285-321. 
Perjanjian perdagangan pasar bebas antara enam negara anggota ASEAN (Indonesia, Thailand, Malaysia, Singapura, Filipina dan Brunei Darussalam) dengan Cina, yang disebut dengan ASEAN - China free trade agreement (ACFTA) membawa pro dan kontra bagi pendapat kalangan pelaku bisnis. Bagi golongan pro,imbas perdagangan China ke Indonesia hanya sebesar $20 \%$ saja, sedangkan keuntungan yang diharapkan lebih dari itu, Indonesia dapat dengan leluasa memasuki perdagangan ke negara China. Namun untuk golangan kontra bahwa keberadaan perjanjian perdagangan pasar bebas dengan negara China dapat berdampak negative. Produksi China sebelum adanya perjanjian ini, mengalir seperti air bah. Apalagi dengan keadaan negara Indonesia yang dianggap sebagai negara berkembang, tidak seperti China yang negara perindustriannya sudah maju, maka Indonesia dianggap kalah bersaing. ( Kompas, "Acfta - Pasar Bebas 2015: "Bunuh Diri Ekonomi Indonesia", artikel diakses pada 12 Januari 2015 dari http://hizbuttahrir.or.id/2014/07/25/acfta-pasar-bebas2010-bunuh-diri- ekonomi-Indonesial. Diakses 27 Januari 2020)

Salah satu pelaku bisnis baju busana muslim di Indonesia mengatakan, bahwa industri yang belum terlalu bersaingan dan pangsa pasarnya cukup dianggap baik dan maju di negara Indonesia adalah bisnis baju busana muslim, persaingan pasar global tidak terlalu berdampak besar terhadap bisnis ini. (Leony Agus Setiawati, Pemilik CV. Rabbani Palu, "Observasi" Tanggal 27 Januari 2020) Maka dari hal tersebutlah industri ini sangat perlu diperhatikan.
Manusia adalah makhluk Tuhan yang paling sempurna yang diciptakan

oleh Allah SWT, dengan segala akal dan pikiranya, manusia harus berusaha mencari solusi hidup yaitudengan bekerja keras mengharap Ridha Allah SWT. Dengan bekerja kita akan mendapatkan balasan yang akan kita terima, apabila seseorang memposisikan pekerjaanya dalam dua konteks, yaitu kebaikan dunia dan kebaikan akhirat, maka hal itu di sebut rezki dan berkah dan hasil pekerjaan yang baik adalah yang dikerjakan dengan penuh tanggung jawab dan sesuai dengan ajaranajaran Rasulullah SAW. ${ }^{3}$

Melihat kaum mayoritas di Indonesia yang sebagian besar beragama Islam, maka dipastikan pangsa pasar bisnis busana muslim akan semakin baik kedepannya. Namun apakah bisnis ini sesuai dengan anjuran Islam yartu sebagai busana penutup aurat bagi umat Islam?, maka ekonomi yang dijalankannyapun tidak bertentangan dengan ekonomi Islam, seperti riba, mengambil hak orang lain, penipuan dan sebagainya. Karena banyak diera modern bisnis-bisnis yang dilakukan hanya sekedar memperkaya individualismenya sendiri, seperti aliran ekonomi yang dipergunakan oleh kaum kapitalisme, yang menganut asas laissez fair, hak kepemilikan perorangan adalah absolute tanpa batas, terjaminnya kebebasan memasuki segala macam kegiatan ekonomi dan transaksi menurut persaingan bebas dan norma-

3 Nuriatullah. Pengaruh Motivasi terhadap peningkatan produktivitas kinerja karyawan pada Tamzis Baituttamwil Area Yogyakarta. Jurnal Ilmu Perbankan dan Keuangan Syariah, 2(1), 24-46. 
norma individual ditarik dari individulisme dan utilitarisme, dimana setiap komoditi itu dianggap baik secara moral dan ekonomi sepanjang itu dapat dijual begitu juga banyak diantaranya usaha bisnis yang tidak mengedepankan keadilan, yaitu aliran ekonomi sosialisme/marxisme, hak milik yang hanya untuk kaum proletar (kaum buruh) yang diwakili oleh kepemimpinan diktator, distribusi faktorfaktor produksi dan apa yang harus diproduksi ditetapkan oleh negara, bagaimana dan untuk siapa produksi yang diatur secara pusat pula, pendapat kolektif dan distribusi yang kolektif adalah norma utama, sedangkan hubungan-hubungan ekonomi dalam transaksi secara perorangan sangat dibatasi. (Ratna Meta Dya, dalam, http:// metakerenz. blogspot. co.id/2009/12/sekelumi usaha bisnis.html, Diakses 27 Januari 2020).

Dari latar belakang sebagaimana yang telah penulis kemukakan sebelumnya, maka penulis akan merumuskan pokok permasalahan yang akan dibahas dalam tulisan ini yaitu bagaimana Tinjauan Ekonomi Islam Terhadap Usaha Bisnis Busana Muslim.

\section{TINJAUAN PUSTAKA}

\subsection{Pengertian antara Ilmu Ekonomi dengan Sistem Ekonomi}

Secara etimologi kata ekonomi berasal dari bahasa oikononemia (Greek atau Yunani), terdiri dari dua kata : oicos yang berarti rumah dan nomos yang berarti aturan. Jadi ekonomi ialah aturan-aturan untuk menyelenggarakan kebutuhan hidup manusia dalam rumah tangga, baik rumah tangga rakyat (volkshuishouding), maupun rumah tangga negara (staathuishouding), yang dalam bahasa inggris disebutnya sebagai economics. (Tim Penyusun Kamus Pusat Bahasa, 2005: 1456)

Sedangkan pengertian ekonomi Islam menurut istilah (terminologi) terdapat pengertian menurut beberapa ahli ekonomi Islam sebagai berikut :

a. Yusuf Qardhawi memberikan pengertian ekonomi Islam adalah ekonomi yang berdasarkan ketuhanan. Sistem ini bertitik tolak dari Allah, bertujuan akhir kepada Allah, dan menggunakan sarana yang tidak lepas dari syari' at Allah. (http://artiekonomiislammenurut pakar, diakses pada tanggal Tanggal 27 Januari 2020)

b. M. Syauqi Al-Faujani memberikan pengertian ekonomi Islam dengan segala aktivitas perekonomian beserta aturan-aturannya yang didasarkan kepada pokok-pokok ajaran Islam tentang ekonomi. (http://www.suryapost.com/2010/1 2/pengertian-ekonomi-islam.html, diakses pada tanggal Tanggal 27 Januari 2020)

c. Monzer Kahf memberikan pengertian ekonomi Islam dengan kajian tentang proses dan penangguhan kegiatan manusia yang berkaitan dengan produksi, distribusi dan konsumsi dalam masyarakat muslim. (http://mduin.blogspot.com/2009/07/pengertian -ekonomi-islam.html, Tanggal 27 Januari 2020).

Masih banyak lagi para ahli yang memberikan definisi tentang apa itu ekonomi Islam. Sehingga ekonomi Islam dapat didefinisikan sebagai suatu prilaku individu muslim dalam setiap 
aktivitas ekonomi syariahnya harus sesuai dengan tuntunan syariat Islam dalam rangka mewujudkan dan menjaga maqashid syariah (agama, jiwa, akal, nasab, dan harta). (Sarkaniputra, 2009: 379)

Islam membedakan antara ilmu ekonomi dan sistem ekonomi. Dalam definisi umum, sistem merupakan keseluruhan yang kompleks, yakni suatu susunan hal atau bagian yang saling berhubungan, sedangkan ilmu adalah pengetahuan yang dirumuskan secara sistematis. Jadi sistem dapat didefinisikan sebagai setiap peraturan yang lahir dari pandangan dunia atau akidah tertentu yang berfungsi untuk memecahkan dan mengatasi problema hidup manusia, menjelaskan bagaimana cara pemecahan, memelihara serta mengembangkannya. (Yusanto dan Yunus, 2009: 13)

Kesimpulan perbedaan antara ilmu ekonomi dan sistem ekonomi muncul karena ada dua fakta berbeda, yaitu :

1. Dalam pemenuhan urusan masyarakat dari segi pemenuhan harta. kekayaan (barang dan jasa) melalui teknik produksi.

2. Dalam pengaturan urusan masyarakat dari segi cara memperoleh, memanfaatkan, dan mendistribusikan kekayaan.

Pembahasan pertama lebih banyak berkaitan dengan kegiatan teknik memperbanyak jumlah barang dan jasa serta bagaimana cara menjaga pengadaannya (produksi), pembahasan ini lebih tepat dikatagorikan dalam ilmu ekonomi. Pembahasan kedua sama sekali tidak dipengaruhi oleh banyak dan sedikitnya kekayaan, tetapi hanya berhubungan dengan tata kerja (mekanisme) pendistribusiannya. Dan ini lebih tepat dikatagorikan sistem ekonomi. (Yusanto dan Yunus, 2009: 16).

\subsection{Bisnis busana muslim dan muslimah}

2.2.1 Pengertian Bisnis

Dewasa ini, semakin banyak masyarakat menggunakan busana muslim. Tidak hanya dipakai pada saat momen hari raya atau pengajian, tetapi juga telah menjadi busana sehari-hari. Keadaan ini ternyata ditangkap oleh produsen busana muslim untuk terus melakukan inovasi, baik dari bahan maupun modelnya. Bisnis busana muslim pun ikut berkembang pesat dan mempunyai peluang yang sangat menjanjikan. Dalam ilmu ekonomi, bisnis adalah suatu organisasi yang menjual barang atau jasa kepada konsumen atau bisnis lainnya, untuk mendapatkan laba. Secara historis kata bisnis dari bahasa Inggris business, dari kata dasar busy yang berarti "sibuk" dalam konteks individu, komunitas, ataupun masyarakat. Dalam artian, sibuk mengerjakan aktivitas dan pekerjaan yang mendatangkan keuntungan.

Secara etimologi, bisnis berarti keadaan dimana seseorang atau sekelompok orang sibuk melakukan pekerjaan yang menghasilkan keuntungan. Kata "bisnis" sendiri memiliki tiga penggunaan, tergantung skupnya - penggunaan singular kata bisnis dapat merujuk pada badan usaha, yaitu kesatuan yuridis (hukum), teknis, dan ekonomis yang bertujuan mencari laba atau keuntungan. Penggunaan yang lebih luas dapat merujuk pada sektor pasar tertentu, misalnya "bisnis pertelevisian." Penggunaan yang paling luas merujuk pada seluruh aktivitas yang dilakukan oleh komunitas 
penyedia barang dan jasa. Meskipun demikian, definisi "bisnis" yang tepat masih menjadi bahan perdebatan hingga saat ini. Sedangkan Secara terminologi, bisnis merupakan suatu kegiatan atau usaha yang dilakukan oleh perorangan maupun kelompok. (Afni, 2007: 12)

Busana muslim sebagai pakaian yang identik dengan umat muslim, kini sudah menjadi busana umum bagi masyarakat Indonesia. Busana muslim merupakan salah satu kebutuhan sandang manusia. Tidak hanya sebagai kebutuhan dasar manusia, berbelanja busana pun sudah menjadi gaya hidup, bahkan hobi seseorang. Pakaian juga dapat menunjukkna status social, golongan, etnis bahkan sifat seseorang. Begitu juga dengan busana yang menunjukkan identitas kepercayaan seseorang seperti busana muslim. (http://khusnul niaga. blogspot.co.id/2014/12/proposal-usahakerudung-muslimah.html, diakses pada tanggal Tanggal 27 Januari 2020)

Karakteristik psikologis yang berbeda dari setiap orang yang memandang responnya terhadap lingkungan yang relative konsisten. Kepribadian dapat merupakan suatu variable yang sangat berguna dalam menganalisis prilaku konsumen. Bila jenis-jenis kepribadian dapat diklasifikasikan dan memiliki korelasi yang kuat antara jenis-jenis kepribadian tersebut dengan berbagai pilihan dan produk. ${ }^{4}$

\subsubsection{Modal}

4 Sofyan Bachmid, dkk, (2020) Analisis faktor-faktor yang mempengaruhi keputusan nasabah dalam memilih produk gadai emas menurut perspektif ekonomi islam. Jurnal Ilmu Perbankan dan Keuangan Syariah, 2(1), 71-86. a. Sumber

Sebelum memulai usaha, satu hal penting yang dibutuhkan adalah modal. Banyak orang yang menganggap bisnis busana muslim memerlukan modal yang besar untuk memulainya. Sebenarnya, besar atau kecilnya modal tergantung dari jenis usaha yang akan di jalankan. Cara mendapatkan modal yang akan digunakan:

1) Tabungan Pribadi

Dalam memulai usaha, harus berani mengambil kesempatan sekecil mungkin. Memang sulit mendapatkan modal yang besar dalam waktu yang singkat. Sebelum mencari modal ke luar, ada baiknya jika menggunakan tabungan pribadi apabila memiliki dan mencukupi. Tidak ada salahnya jika menggunakan uang tabungan sebagai modal awal apabila mencukupi. (http://seribu peluang. blogspot.com 2015/02/ peluang -usaha-toko-busanamuslim.html, diakses pada tanggal Tanggal 27 Januari 2020).

Ada kelebihan dan kekurangan bila menggunakan tabungan pribadi sebagai modal awal. Kelebihan yang akan didapat sebagai pemodal tunggal, antara lain dapat mengelola usaha secara maksimal seorang diri. Disamping itu, keputusan-keputusan yang diambil akan menjadi tanggung jawab pribadi tanpa menimbulkan pertentangan dan laba yang akan didapat menjadi milik sepenuhnya tanpa perlu dibagi dengan orang lain. Kekurangan saat menjadi pemodal tunggal ialah saat terjadi masalah bisnis, harus menyelesaikanya seseorang diri. Begitu juga beban kerugian yang harus ditanggung. Dalam hal modal, jika tidak berhati-hati dalam pengelolaannya, akan mengalami kerugian besar saat bisnie jatuh. 
2) Patungan dengan Teman

Membuka usaha dengan rekan sama dengan membagi modal, tanggung jawab, dan risiko. Dengan modal awal yang ditanggung bersama maka beban akan ditanggung bersama pula. Risiko yang diterima juga lebih sedikit karena dengan bekerja sama dapat memecahkan permasalahan yang muncul bersama-sama. Karena semuanya ditanggung bersama, dari awal perlu menekankan kepercayaan dan kejujuran agar ke depannya tidak terjadi kesalah pahaman yang berakibat hancurnya usaha.

Berbisnis bersama teman memiliki kelebihan dan kekurangan. Kelebihannya adalah keputusan maupun permasalahan yang timbul dapat diselesaikan secara bersama. Akan tetapi, pada saat terjadi pertentangan pendapat apalagi apabila masingmasing berpendirian kuat atau keras kepala, akan susah mencari solusi permasalahan dan pemecahannya. Kelebihan dari system rekanan ini adalah saat keputusan maupun permasalahan yang timbul dapat diselesaikan secara bersama.

3) Menjual atau Gadai Barang

Solusi lain untuk mencari modal adalah dengan menjual atau menggadai barang-barang yang dimiliki. Barangbarang yang dapat digadai atau dijual itu biasanya merupakan barang berharga, seperti emas, mobil, atau rumah. Menggadai atau menjual barang memang memiliki keuntungan, salah satunya akan mendapatkan modal yang dibutuhkan dengan cepat. Gadai juga memiliki kelemahan yaitu jumlah dana yang didapatkan terbatas dengan waktu peminjaman yang cukup singkat. Sedangkan kelemahan menjual barang adalah kegunaan barang tersebut yang suatu waktu bisa dipakai lagi. (http://www. investasi. web.id/net/ contohmakalah-tentang-busana-muslim-dan-

muslimah. html/ diakses pada tanggal Tanggal 27 Januari 2020)

\section{4) Pinjaman dari Investor}

Investor adalah orang yang menanamkan modal atau uangnya untuk berinvestasi membuka usaha dengan tujuan mendapatkan keuntungan. Pembagian keuntungan dengan memberi sekian persen dari total laba bersih usaha kepada investor. bisa juga system pembagian keuntungan dengan membagi keuntungan sekian rupiah dari setiap hasil penjualan busana atau aksesoris.

5) Bank

Akibat resesi belakangan ini, proses peminjaman bank menjadi semakin rumit dengan berbagai syarat dan ketentuan. Dengan meminjam uang di bank, akan mendapatkan modal yang lebih besar dan cepat. Akan tetapi untuk berbagai jenis kredit, bank mempunyai syarat jaminan yang setimpal dengan besarnya pinjaman yang diajukan bahkan cenderung lebih tinggi nilai jaminan dibandingkan nominal pinjaman yang diajukan. (http://istieaquarius girl.blogspot.co.id/2013/05/bisnis-busanamuslim.html, diakses pada tanggal Tanggal 27 Januari 2020)

\subsubsection{Sistem Perolehan}

Dalam pengadaan dana, ada dua macam system yaitu pengadaan secara tunai dan kredit.

\section{a) Tunai}

Pengadaan modal dengan sistem tuani adalah modal tunai yang dimiliki seseorang untuk memulai usaha. Dengan menggunakan uang tunai yang didapat ataupun dimilikinya, pengusaha 
dapat membuka usaha dengan membelajakan uang tersebut sesuai dengan keinginannya.

b) Kredit

Pengambilan kredit sebaiknya disesuaikan dengan kemampuan dalam mengembalikannya. Kredit yang diterima adalah utang, pengembaliannya pun ditambah dengan bunga yang harus dibayar di kemudian hari.

c) Jumlah Modal

Jumlah modal yang diperlukan tentu berhubungan dengan usaha yang akan dijalankan. Semakin besar jumlah modal yang dimiliki maka semakin besar pula usaha yang dapat dijalankan. Perkiraan besar modal yang akan digunakan untuk membuka usaha sangat beragam. 2.2.4 Lokasi dan Tempat Usaha

Ada beberapa syarat dalam menentukan lokasi usaha busana muslim, diantaranya lokasi usaha mempunyai akses yang mudah dijangkau dengan kata lain lokasinya strategis. Apabila lokasi jauh dari pemukiman atau jalan raya, usaha akan sulit berkembang karena lokasinya yang kurang strategis. Pasar atau Mall merupakan salah satu tempat yang dapat digunakan untuk usaha ini.

Ketersediaan tempat parkir juga menjadi pertimbangan. Dengan adanya tempat parkir, akan memudahkan konsumen meletakkan kendaraan dan akan merasa aman ketika kendaraan berada di depan toko. Selain factor tersebut diatas juga diperhatikan factor saingan usaha di sekeliling.

2.2.5 Pemasaran dan Promosi

Cara pemasaran yang baik mempengaruhi an mendukung keberhasilan bisnis. Dengan kata lain, promosi berkaitan dengan volume penjualan. Kegiatan promosi dimaksudkan untuk menyebarluaskan informasi tentang barang dagangan yang dijual. Berdasarkan sasarannya promosi penjualan dapat diklasifikasikan menjadi 3 bagian:

a) Promosi untuk konsumen, misanya dengan memberikan konsumen produk sampel,kupon berhadiah, hadiah langsung, potongan harga dan sebagainya.

b) Promosi dagang, misalnya kredit pembelian, hadiah pembelian, dan sebagainya.

c) Promosi bisnis, misalnya sponsor pertunjukan, peragaan dalam pertunjukan, kontes penjualan dan sebagainya. (Afni, 2007: 56)

Ada beberapa cara untuk mendongkrak penjualan diantaranya adalah sebagai berikut:

a) Promosi menggunakan iklan

b) Promosi melalui internet

c) Promosi melalui ponsel

d) Promosi dengan memberikan potongan harga

e) Memberikan pelayanan yang terbaik.

f) Promosi dari mulut ke mulut

g) Promosi melalui media cetak

h) Promosi melalui kartu nama. (Afni, 2007: 56)

Faktor-faktor yang mempengaruhi volume penjualan yaitu

a) Kualitas barang

Tinggi rendahnya mutu suatu barang, sangat mempengaruhi volume penjualan. Biasanya sebagian konsumen tidak akan ragu merogoh kocek yang lebih dalam asalkan barang yang didapatkan berkualitas.

b) Membaca trend pasar

Selera konsumen tidaklah tetap dan berubah setiap saat. Apabila selera konsumen terhadap barang-barang yang dijual berubah, maka volume penjualan akan menurun. Dengan demikian 
membaca trend pasar sangat penting dalam menarik pasar.

c) Pelayanan terhadap pelanggan

Memberikan pelayanan terbaik merupakan factor penting dalam usaha memperlancar meningkatkan volume penjualan.

d) Memperhatikan pesaing

Mempelajari kelebihan dan kekurangan pesaing karena diharapkan dapat mencontoh kelebihan pesaing dan menghindari kekurangan pesaing.

e) Menata toko

Mendesain interior sebaik mungkin untuk menarik perhatian konsumen/pembeli. (Afni, 2007: 56)

\section{METHODOLOGY}

Dalam penulisan karya ilmiah ini, penulis menggunakan metode pendekatan penelitian deskripsi kualitatif, yaitu memaparkan aspek-aspek yang menjadi sasaran penelitian penulis. Pendekatan yang dimaksud yaitu suatu penelitian yang berusaha untuk menuturkan pemecahan masalah yang ada sekarang berdasarkan data-data, sehingga penulis dapat menemukan kepastian dan keaslian data untuk diuraikan sebagai hasil penelitian yang akurat. ${ }^{5}$ Penelitian yang bersifat deskriptif menurut Suharsimi Arikunto "lebih tetap apabila menggunakan pendekatan kualitatif".6,7

5 Evita, E., Syahid, A., \& Nurdin, N. (2019). Understanding Students' Learning Outcomes Differences Through the Application of the Market Place Activity Type of Cooperative Learning Model and the Application of Conventional Learning Models International Journal of Contemporary Islamic Education, 1(1), 6785.

${ }^{6}$ Suharsimi Arikunto, Prosedur Penelitian Ilmiah, Suatu Pendekatan Praktek,Ed. II, (Cet. IX ; Jakarta : Rineka Cipta, 1993)h 209;

${ }^{7}$ Nurdin, N., Stockdale, R., \& Scheepers, H. (2014b, 6-9 Jan. 2014). The Role of Social
Adapun yang menjadi objek atau sasaran lokasi penelitian adalah Usaha Busana Muslim Yang ada di Kota Palu. Ini menunjukan bawah lokasi penelitian di anggap sangat representatif terhadap judul penelitian yang diangkat penulis, karena disamping objek dianggap tepat, juga memberikan nuansa baru bagi penelitian dalam menambang pengalaman penelitian, khususnya pada Busana Muslim

Data dikumpul melalui observasi, wawancara mendalam, dan dari berbagai dokumen yang ada. Dalam wawancara peneliti melakukan wawancara langsung dengan pemiliki usaha busana muslim yang dapat memberikan data yang menyakut masalah atau objek penelitian.

\section{HASIL DAN PEMBAHASAN}

\subsection{Nilai-nilai dasar ekonomi islam}

Nilai-nilai dasar ekonomi Islam adalah seperangkat nilai yang telah diyakini dengan segenap keimanan, dimana ia akan menjadi landasan paradigma ekonomi Islam. Nilainilai dasar ini baik nilai filosofis, instrumental maupun institusional didasarkan atas Al-Qur'an dan Hadist yang merupakan dua sumber normativ tertinggi dalam agama Islam. Inilah hal utama yang membedakan ekonomi Islam dengan ekonomi konvensional, yaitu ditempatkannya sumber ajaran agama sebagai sumber utama ilmu ekonomi. Tentu saja, Al-Qur'an dan Hadist bukanlah merupakan suatu sumber yang secara instan menjadi ilmu

Actors in the Sustainability of E-Government Implementation and Use: Experience from Indonesian Regencies. System Sciences (HICSS), 2014 47th Hawaii International Conference on System Science, 
pengetahuan. Untuk mengubah nilai dan etika Islam menjadi suatu peralatan operasional yang berupa analisis ilmiah, maka suatu filsafat etika harus disusutkan (diperas) menjadi sekumpulan aksioma yang kemudian dapat berlaku sebagai suatu titik mula pembuat kesimpulan logis mengenai kaidah-kaidah sosial dan perilaku ekonomi yang Islami, inilah yang dimaksud dengan nilai dasar ekonomi Islam dalam pembahasan ini, yang sesungguhnya merupakan derivatif dari ajaran Islam dalam bentuk yang lebih fokus.

Ada beberapa nilai yang menjadi sumber dari dasar sistem ekonomi Islam, antara lain:

\section{a. Kepemilikan}

Nilai dasar pemilikan dalam sistem Ekonomi Islam:

1) Pemilikan terletak pada kepemilikan pemanfaatannya dan bukan menguasai secara mutlak terhadap sumber-sumber ekonomi.

2) Pemilikan terbatas pada sepanjang umurnya selama hidup di dunia, dan bila orang itu mati, harus didistribusikan kepada ahli warisnya menurut ketentuan Islam. 3. Pemilikan perorangan tidak dibolehkan terhadap sumber-sumber yang menyangkut kepentingan umum atau menjadi hajat hidup orang banyak. (Saefuddin, 2003: 43-49)

\section{b. Keseimbangan}

Merupakan nilai dasar yang pengaruhnya terlihat pada berbagai aspek tingkah laku ekonomi muslim, misal kesederhanaan (moderation), berhemat (parsimony), dan menjauhi pemborosan (extravagance). Konsep nilai kesederhanaan berlaku dalam tingkah laku ekonomi, terutama dalam menjauhi konsumerisme, dan menjauhi pemborosan berlaku tidak hanya untuk pembelanjaan yang diharamkan saja, tetapi juga pembelanjaan dan sedekah yang berlebihan. (Saefuddin, 2003: 50) Sebagaimana Firman Allah SWT dalam QS. Al-furqan (25): 67

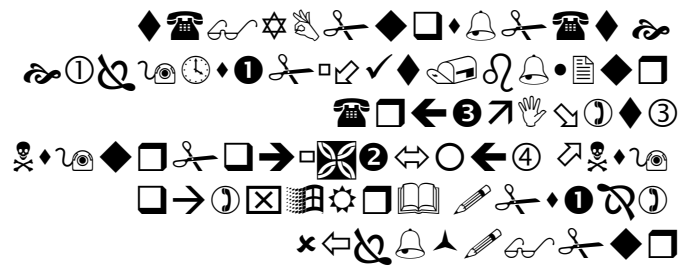

Terjemahnya: Dan orang-orang apabila membelanjakan (harta) mereka tidak berlebihan, dan tidak (pula) kikir, dan adalah (pembelanjaan itu) ditengah tengah orang yang demikian. (Departemen Agama RI, 2008: 561)

Nilai dasar keseimbangan ini selain mengutamakan kepentingan dunia dan kepentingan akhirat, juga mengutamakan kepentingan perorangan dan kepentingan umum, dengan dipeliharanya keseimbangan antara hak dan kewaj iban. (Sardiman, 2008: 23)

c. Keadilan

Secara garis besar keadilan dapat didefinisikan sebagai suatu keadaan dimana terdapat kesamaan perlakuan di mata hukum, kesamaan hak kompensasi, hak hidup secara layak, dan hak menikmati pembangunan. (Ali, 2009: 5)

\subsection{Nilai-nilai dasar ekonomi islam \\ Menurut As-Shatibi tujuan} utama syariat Islam adalah mencapai kesejahteraan manusia yang terletak pada perlindungan terhadap lima kemashlahahan, yaitu keimanan (ad-dien), ilmu (al-,i1m), kehidupan (annafs), harta (al-maal), dan kelangsungan keturunan 
(an-nasl). (Ali, 2009: 8). Mashlahah dicapai hanya jika kehidupan manusia hidup dalam keseimbangan, diantaranya mencakup keseimbangan antara moral dan spiritual sehingga terciptanya kesejahteraan yang hakiki. Tujuan ekonomi Islam lainnya menggunakan pendekatan antara lain :

a. Konsumsi manusia dibatasi sampai pada tingkat yang dibutuhkan dan bermanfaat bagi kehidupan manusia.

b. Alat pemuas kebutuhan manusia seimbang dengan tingkat kualitas manusia agar ia mampu meningkatkan kecerdasan dan kemampuan teknologinya guna menggali sumber-sumber yang masih terpendam.

c. Dalam pengaturan distribusi dan sirkulasi barang dan jasa, nilai-nilai moral harus diterapkan.

d. Pemerataan pendapatan dilakukan dengan mengingat sumber kekayaan seseorang yang diperoleh dari usaha halal, maka zakat sebagai sarana distribusi pendapatan merupakan sarana yang ampuh. (Fadullah, 2008: 45)

Secara umum tujuan ekonomi dalam Islam adalah untuk menciptakan al-falah atau kemenangan, keselamatan dan kebahagian dunia dan akhirat. Untuk mencapai hal demikian maka manusia harus bekerja keras mencari rezeki dalam rangka memenuhi kebutuhankebutuhan hidupnya baik yang bersifat materi maupun non material (rohaniah), serta berbuat baik dengan harta yang dimilikinya dengan memperhatikan nilai-nilai dan normanorma ajaran Islam, berupa pelaksanaan perintahnya dan menjauhkan larangannya agar tercipta kemashlahatan yang sesungguhnya baik untuk dirinya sendiri dan orang lain.(Abbas, 2009: 14)

Usaha individu yang terorganisir untuk menghasilkan dan menjual barang dan jasa guna mendapatkan keuntungan dalam memenuhi kebutuhan masyarakat. Pendapat lain menyatakan bahwa bisnis adalah sejumlah total usaha yang meliputi pertanian, produksi, konstruksi, distribusi, transportasi, komunikasi, usaha jasa yang bergerak dalam bidang membuat dan memasarkan barang dan jasa konsumen. (Alma, 1998: 21)

Dalam kaitannya dengan bisnis sebenarnya manusia telah banyak dianugrahi berbagai macam fasilitas untuk mendapatkan rezeki diantaranya yaitu bumi, dengan segala isinya, semua itu di instruksikan untuk dikelola dan dikembangkan dalam upaya peningkatan kehidupan manusia Namun semua itu harus melalui kode etik halalan-thayyiban mulai dari cara memperolehnya sampai kepada pendayagunaannya. (Alma, 1998: 22) sebagaimana diungkap oleh Allah dalam surat An-Nisa (4) : 29 Allah berfirman :

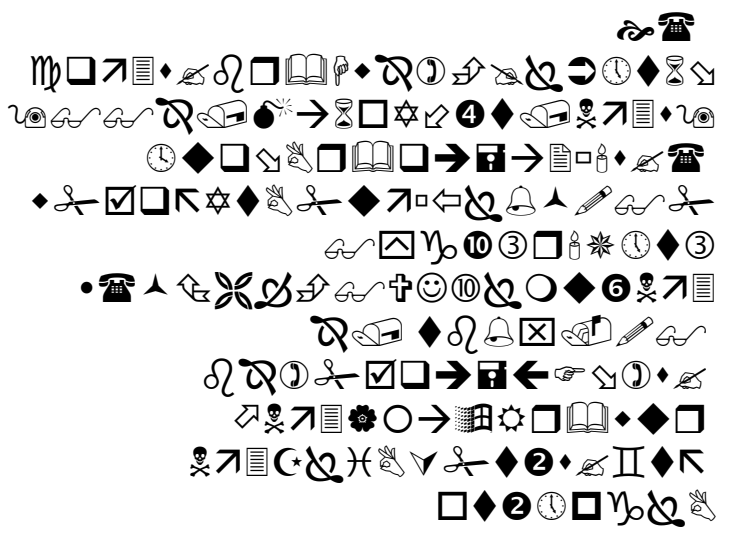

Terjemahnya: Hai orang-orang yang beriman janganlah kamu saling memakan harta sesamamu dengan jalan yang batil, kecuali dengan jalan perniagaan yang berlaku dengan suka- 
suka diantara kamu dan janganlah kamu membunuh dirimu, sesungguhnya Allah adalah maha penyayang kepadamu. (Departemen Agama RI, 2008: 119)

Dengan demikian, maka bisnis menurut Islam dapat diartikan serangkaian aktivitas bisnis dalam berbagai bentuknya yang tidak dibatasi jumlah (kuantitas) kepemilikan hartanya (barang/jasa) termasuk profitnya, namun dibatasi dalam cara dan perolehan dan pendayagunaan hartanya (aturan halal dan haram). Dengan kendali syari'at, bisnis bertujuan untuk mencapai empat hal yakni target hasil (profit materi dan benerfit non materi), pertumbuhan artinya terus meningkat, keberlangsungan dalam kurun waktu selama mungkin dan keberkahan keridhaan Allah SWT. (Suparlan, 2008: 24) Jumlah (kuantitas) kepemilikan hartanya (barang/jasa) termasuk profitnya, namun dibatasi dalam cara dan perolehan dan pendayagunaan hartanya (aturan halal dan haram).

Dengan kendali syari'at, bisnis bertujuan untuk mencapai empat hal yakni target hasil (profit materi dan benerfit non materi), pertumbuhan artinya terus meningkat, keberlangsungan dalam kurun waktu selama mungkin dan keberkahan keridhaan Allah SWT.

\subsection{Manajemen Keuangan Islam}

Pengertian Manajemen Keuangan mengalami perkembangan mulai dari pengertian manajemen yang hanya mengutamakan aktivitas memperoleh dana saja sampai yang mengutamakan aktivitas memperoleh dan menggunakan dana serta pengelolaan terhadap aktiva. Beberapa definisi manajemen keuangan diberikan sebagai berikut:
1. Liefman: usaha untuk menyediakan uang dan menggunakan uang untuk mendapat atau memperoleh aktiva.

2. James Van Horne: segala aktivitas yang berhubungan dengan perolehan, pendanaan dan pengelolaan aktiva dengan tujuan menyeluruh.

3. Bambang Riyanto: keseluruhan aktivitas perusahaan yang berhubungan dengan usaha mendapatkan dana yang diperlukan dengan biaya yang minimal dan syarat-syarat yang paling menguntungkan beserta usaha untuk menggunakan dana tersebut seefisien mungkin. (Suparlan, 2008: 24)

Pengertian diatas dapat ditarik beberapa kesimpulan bahwa manajemen keuangan berhubungan dengan tiga aktivitas (fungsi) utama.

1. Allocation of funds (aktivitas penggunaan dana) yaitu aktivitas untuk menginvestasikan dana pada berbagai aktiva. Alokasi dana berbentuk:

a. Financial assets (aktiva finansial) yaitu selembar kertas berharga yang mempunyai nilai pasar karena mempunyai hak memperoleh penghasilan, misalnya: saham, sertifikat deposito, atau obligasi.

b. Real assets (aktiva rill) yaitu aktiva nyata: tanah, bangunan, peralatan.

2. Raising of funds (aktivitas perolehan dana) yaitu aktivitas untuk mendapatkan sumber dana baik dari sumber internal perusahaan maupun sumber eksternal perusahaan, termasuk juga politik dividen. Sumber dana pada perusahaan secara keseluruhan. 
3. Manajemen assets (aktivitas pengelolaan aktiva) yaitu setelah dana diperoleh dan dialokasikan dalam bentuk aktiva-aktiva harus dikelola seefisien mungkin. (Yusanto dan Widjajakusuma, 2002), 18)

Analisis aspek keuangan suatu usaha perlu dilakukan untuk mengetahui gambaran umum mengenai pendapatan dan pengeluaran atau biaya, kemampuan melunasi kredit (jika usaha tersebut mendapatkan pendanaan secara kredit dari lembaga perbankan atau non bank), serta kelayakan usaha ditinjau dari beberapa kriteria kelayakan keuangan seperti Net Present Value (NPV), Internal Rate of Return (IRR), Pay Back Period (PBP) dan Net Benefit/Cost Ratio (Net B/C). Analisis keuangan suatu usaha terdiri dari proyeksi penerimaan dan proyeksi pengeluaran selama periode proyek.(Sardjan, 2002: 23)

Dalam hukum keuangan Islam dibahas bahwa dalam mengelola atau menajemen keuangan harus dilandasi dengan eksplorasi nilai-nilai Islam, yang berpijak pada tujuan maqhasid syariah dengan mewujudkannya nilai keadilan dan kebenaran. Point penting yang harus diingat, bahwa laba (keuntungan) dalam bisnis syariah tidak selalu identik dengan materil, pertumbuhan aset atau harta. Laba dalam Islam memiliki dua orientasi yaitu Materil dan Nonmateril. Aspek Materil dari laba dimaknai dengan penambahan harta yang halal dan bersih dari seorang pebisnis muslim. Sedang aspek NonMateril, laba sangat erat kaitannya dengan: ketakwaan, kesabaran, bersyukur, mengikuti perintah Rasullullah SAW serta dipelihara dari kekikiran. (Sardjan, 2002: 23)
Dampak dari implementasi konsep laba dalam Islam adalah semua pebisnis dalam menjalankan usaha akan selalu menjaga diri dari perbuatan tercela, tidak amanah, penipuan, peng-rusakan lingkungan, dan perbuatan tercela lainnya yang dilarang syariah. Keuntungan yang didapat pun tidak akan ter-akumulasi pada diri mereka sendiri melainkan terdistribusi secara proporsional juga kepada masyarakat kurang mampu. Dalam jangka panjang, penerapan konsep laba ini akan mengarah pada terciptanya suatu tatanan kehidupan ekonomi yang sejahtera dan berkeadilan, tatanan kehidupan sosial yang saling menghargai, menghormati dan tolong menolong di antara seluruh masyarakat.

\section{DAFTAR PUSTAKA}

Abbas, Anwar. Dasar-Dasar Sistem Ekonomi Islam. Jakarta: Fakultas Syariah Dan Hukum, Uin Syahid, 2009

Afni, Nur. Etika Bisnis. Jakarta: Rajawali, 2007

Ali, Zainuddin. Hukum Ekonomi Syariah. Jakarta: Sinar Grafika, 2009

Alma, Buchari. Pengantar Bisnis. Bandung : Alfabeta, 1998.

Departemen Agama RI. Alqur'an dan Terjemahnya. Jakarta: CV.Toha Putra, 2008

Evita, E., Syahid, A., \& Nurdin, N. (2019). Understanding Students' Learning Outcomes Differences Through the Application of the Market Place Activity Type of Cooperative Learning Model and the Application of Conventional Learning Models International 
Journal of Contemporary Islamic Education, 1(1), 67-85.

Fadlullah. Orientasi Baru Pendidikan Islam. Jakarta: Diadit Media, 2008

http://artiekonomiislammenurut pakar Diakses 27 Januari 2020

http://istieaquariusgirl.blogspot.co.id/2013/ 05/bisnis-busana-muslim.html,

Diakses 27 Januari 2020

http://khusnulniaga.blogspot.co.id/2014/12 proposal-usaha-kerudun muslimah.html, Diakses 27 Januari 2020

http://mduin.blogspot.com/2009/07/p engertian-ekonomi-islam.html,

Diakses 27 Januari 2020

http://seribupeluang.blogspot.com/2015/02/ peluang-usaha-toko-busanamuslim.html, Diakses 27 Januari 2020

http://www.investasi.web.id/net/contohmakalah-tentang-busana-muslimdan- muslimah.html/, Diakses 27 Januari 2020

http:/ / www.suryapost.com/2010/12/pe ngertian-ekonomi-islam.html, Diakses 27 Januari 2020

Jusmalinani.Bisnis Berbasis Syariah. Jakarta: Bumi Aksara, 2008

Kompas, "Acfta - Pasar Bebas 2015: "Bunuh Diri Ekonomi Indonesia", artikel diakses pada 12 Januari 2015 dari http://hizbuttahrir.or.id/2014/07/25/acfta-pasarbebas-2010-bunuh-diri- ekonomiIndonesia/. Diakses 27 Januari 2020

Muhammad. Prinsip-prinsip Ekonomi Islam. Yogyakarta: Graha Ilmu, 2007
Nurdin, N., Novia, N., Rahman, A., \& Suhada, R. (2019). Potensi Industri Produk Makanan Halal Di Kota Palu. Jurnal Ilmu Ekonomi dan Bisnis Islam, 1(1), 1-12.

Nurdin, N., Stockdale, R., \& Scheepers, H. (2014b, 6-9 Jan. 2014). The Role of Social Actors in the Sustainability of E-Government Implementation and Use: Experience from Indonesian Regencies. System Sciences (HICSS), 2014 47th Hawaii International Conference on System Science

Nurdin, N., \& Mir'atun, M. a. (2018). Do Government And Private Sharia Commercial Banks Practice Similar Financial Social Responsibility Disclosure. Hunafa: Jurnal Studia Islamika, 15(2), 285321.

Ratna Meta, Dya. dalam, http://metakerenz.blogspot.co .id/2009/12/sekelumi usaha bisnis.html, Diakses 27 Januari 2020

Saefuddin, Ahmad M. Studi Nilai-Nilai Sistem Ekonomi Islam. Jakarta: Media Da'wah dan LIPPM, 2003

Sardiman. Ekonomi Islam. Jakarta: PT RajaGrafindo Persada, 2008

Sardjan. Perencanaan Keuangan. Jakarta : Ciputat Press, 2002.

Sarkaniputra, Murasa. "Ruqyah Syar'iyyah (Teori, Model Dan Sistem Ekonomi). Jakarta : AlIshlah Press Dan STEI, 2009.

Suparlan. Kajian Ekonomi Islam. Bandung: Gema Persada, 2008 
Tim Penyusun Kamus Pusat Bahasa. Kamus Besar Bahasa Indonesia. Jakarta: Balai Pustaka, 2005

Yusanto, Ismail dan Widjajakusuma, Yusanto, M. Ismail Dan Yunus, M. Arif. Pengantar Ekonomi Islam. Bogor : AlAzhar Press, 2009

Karebet. Menggagas Bisnis Islam. Jakarta: Gema Insane Press, 2002 